\title{
Globalization And The Automobile Sector of Nigeria (1990-2015)
}

\author{
ChukwurahDaniel ${ }^{1}$, OnwukaEbele ${ }^{2}$, Okoye NonsoSunday ${ }^{3}$, \\ DibuaChijiokeEmmanuel $^{4}$, and EzeanyimEkene ${ }^{5}$ \\ ${ }^{I}$ Department of Public Administration, Faculty of Management Sciences, Nnamdi Azikiwe University, Awka \\ ${ }^{2,3,4}$ Department of Business Administration Faculty of Management SciencesNnamdi Azikiwe University, Awka \\ ${ }^{5}$ Department of Business Administration and Management, Anambra State College of Agriculture, Mgbakwu.
}

\begin{abstract}
This study examined the influence of globalization on automobile sector of Nigeria (1990-2015). The study identified obsolete technology, negative effect of trade openness, inadequate manufacturing infrastructure, low capacity utilization and industrial production as the problems facing Nigeria automobile sector. In view of the above problems, the study sought toexamine the extent of relationship between Foreign Direct Investments (FDI) and manufacturing output of automobile industry, to ascertain the value added by Information and Communication Technology (ICT) penetration on employment in the automobile industry and to determine the influence of trade openness on capacity utilization in the automobile industry. The study was anchored on theory of globalization by Glovanni (2001). Secondary data were sourced from Central Bank of Nigeria statistical bulletin and publications from the National Bureau of Statistics. Ordinary Least Square technique was used for the study. The result revealed that Manufacturing Output has a significant effect on automobile industry; Employment has a positive relationship with Foreign Direct Investment, Information and Communication Technology (ICT) penetration and Trade Openness. While Capacity Utilization has a positive relationship with Industrial Production and Technology Transfer. The study concludes that for a country to maximally enjoy the benefits and maximize the risks associated with globalization, it has to develop and strength its capacity to timely identify both internal and external shocks, and to initiate, design and implement appropriate policies to forestall their destabilizing effects. It is on the basis of the foregoing that Nigeria can be put on the right track in the race towards sustainable development. The study recommended that Nigeria should take a second look at her membership of the WTO and then selectively engage in those trades that will not jeopardize her national interest, most especially the imperative need to protect Nigeria automobile subsector.
\end{abstract}

Keywords: Capacity Utilization,FDI,Globalization, ICT, Manufacturing Output,Real Sector, Trade Openness, WTO.

\subsection{Background of the Study}

\section{Introduction}

Globalisationdates back to the $6^{\text {th }}$ century (Saches and Warner, 1995) and is not new. The United Nations Development Programme (UNDP) report (1999) confirms that globalisation is not a new phenomenon, but that the wind ofglobalisation differs from those of the $16^{\text {th }}$ century and or beginning of the $20^{\text {th }}$ century.Globalisation is characterized by new interconnected markets, operating 24hours a day in real time, enhance by new means of communication such as internet, mobile phones, media, transnational or multinational companies, regional bloc and new rules (mutilated agreements which significantly constrain the span of national policies, international agreements, and global agenda on various issues).

Obadan (2002)opined that rapid economic growth and prosperity in the Asian developing countries is derived from their ability to manufacture, produce and export goods in which they have comparative advantage. In addition, the Nigeria manufacturing sector is characterized by increasing cost of production emanated from high tariff, increased cost of energy input, reliance on poor and inadequate public sector infrastructures and rising cost of import, Nigeria is not exempted and is worse off by the sharp depression of the naira exchange rate (Oluwole, 2013).This makes it difficult for Nigeria manufacturing sector to take advantage of the opportunities offered by globalisation.

Since the National Automotive Industry Plan (NAIDP) was announced by the Federal Government in October 2013, the Nigerian automotive industry has witnessed serious interest from global and local automobile brands in setting up and doing business in a very promising sector and this has been a welcome development, but my premise has yet remained that - the Nigeria automotive industry should begin to look beyond assemblage to primary 
production, manufacturing and exportation because we are still trailing behind in consideration of our production capacity, availability of raw materials, political will, technological know-how and market.

However, we should nonetheless be grateful for the kind of interest the sector is already generating, It is a known fact that all over the world, big car manufacturers such as Nissan, GM, Toyota, VW produce only $30 \%$ of over 2000 parts of the vehicle components outsourcing the remaining $70 \%$ to component suppliers to provide thereby creating an avenue for growing local production capacity as well as creating direct employment. In this brief write-up, we will attempt to look at government's effort in re-establishing the sector, private initiatives in taking advantages of the conducive environment provided by government and the foray of foreign investors in the Nigerian automotive industry yet so far.

Government should be applauded for putting into place the National Automotive Industry plan (NAIDP) as this has proactively charted a course for a proper auto policy frame work in the country, shortly before this policy was put in place in 2013, Nigeria and Bangladesh were the only countries in the top 10 by population without a developed automotive road map. The auto sector is a key component in the Nigerian Industrial Revolution Plan (NIRP), the NIRP is a 5-years programme developed by the Ministry of industry, Trade and Investments to help diversify the country's economy and revenue through industry and to increase manufacturing's contribution to GDP to at least $6 \%$ this year and finally above $10 \%$ by year 2017 and the automotive industry has been classified strategic in this quest. The government believes that Nigeria is well positioned to be a major assembly hub for the International auto companies due to our existing installed auto capacity, large labour force and significant local demand and also a strategic location for export hence government is taking steps to making sure the industry takes its pride of place by providing the necessary regulations, working business environment and even funding in some quotas.

International auto companies who are looking at expanding their market base are already stationing in Nigeria because of the massive investment opportunity the country is providing, within a space of four months after the policy was put in place by government, private investment interest soared to an unexpected level with the announcement of plans by some reputable Original Equipment Manufacturers, OEMs to establish their assembly plants in Nigeria.

It took several years for some automobile manufacturing countries, like South Africa, to attract the level of attention and interest Nigeria got within four months of establishing the auto policy, rather than go to each of the OEMs to convince them to come, like South Africa did, they are lining up to come to Nigeria.

It is however realistic to stress that no meaningful economic growth, wealth creation, employment generation and poverty reduction can be achieved in any country without a robust manufacturingsector which is the real sector of the economy. This therefore depicts the importance of the real sector in the growth of the Nigeria economy as it facilitates the use of human resources in the procurement of raw materials and in the production and distribution of goods. This work seeks to examine the effect of globalisation on Nigerian automobile sector.

\subsection{Statement of the Problem}

Globalisation is a process of interaction and integration among people, companies and government of different nations (Satish, 2003). It is driven by international trade and investment and aided by information and Communication Technology (ICT).

Nevertheless, despite the seeming benefits of globalisation in the activities of modern businesses especially those in the manufacturing sector, the process has not had proper impact onthe Nigerian manufacturing sector. The manufacturing sector, especially the automobile industry is on the verge of collapse after 20 years of military rulewith thousands of workers being thrown out ofjobs. Again, Nigeria had also become a dumping ground for all kinds of foreign made automobile and fairly used automobiles popularly known as 'Tokunbo' carsdespite the government's effort to improve its industrial production and capacity utilization which was below 30percent.The Nigerian automobile sector is faced a lot of problems ranging from the challengeof advanced technology, inadequate transfer of technology, corruption, lack of technical know-how, enabling environment through tax exemptions, and low capacityutilization (Amakom, 2008).

Furthermore, Nigerian automobile industry is faced with problem of trade openness. Trade openness undermine growth in the manufacturing sector as it exposes Nigerian automobile industries to competition from global corporation who often have better financing,technology and market reach. With increasing breakdown of barriers in Nigerian automobile sector, developed nations have therefore taken advantage of trade openness thereby seeking market to dump their fairly used cars and rendering the automobile industry unproductive as the demand for made in Nigeria cars declined.In the same vein, Foreign Direct Investment (FDI) has not been fully encouraged by 
Globalization And The Automobile Sector of Nigeria (1990-2015)

the Nigerian Government with its inability to tackle adequately, the problems of insurgency in the nation and providing adequate security for potential investors in the Nigerian automobile industry (Agbelogode, 1999).

Abubakar (2001) contended that the process of globalisation is associated with harsh socio economic condition. From the above, it is an establish fact that globalisation is associated with some risks and cost which have adverse implication for the manufacturing sector which is at the verge of collapse. These have resulted in Nigeria being a dumping ground for all kind of fairly used cars.

There is thus the inevitable need to turn the search light on globalization and all that accompanied it and examine its impact on the Nigerian manufacturing sector with particular reference to the automobile industry.

\subsection{Objectives of the Study}

The broad objective of the study is to examine the influence of globalization on Nigerian automobile subsector. While, the study specifically seeks;

1. To examine the extent of relationship betweenForeign Direct Investments (FDI) andmanufacturingoutput of automobile industry.

2. To ascertain the value added byInformation and Communication Technology (ICT) penetration on employment in the automobile industry.

3. To determine the influence oftrade openness on capacity utilization in the automobile industry.

For the purpose of this study, globalization was decomposed into Foreign Direct Investment (FDI), which was proxied with import, export and balance of payment, Information and Communication Technology (ICT) Penetration, which was proxied with technology transfer, manpower training, standard of living and industrial production and Capacity Utilization, wasproxied with Capacity Utilization, Technology Transfer,Trade Opennessand Industrial Production. Manufacturing was decomposed into manufacturing output, Employment and Capacity Utilisation

\subsection{Research Questions}

1. What is the extent of relationship between Foreign Direct Investments (FDI) and manufacturing output of automobile industry?

2. What is the value added by Information and Communication Technology (ICT) penetration on employment in the automobile industry?

3. What is the influence of trade openness on capacity utilization in the automobile industry?

\subsection{Research Hypotheses}

$\mathrm{H}_{\mathrm{i}}$ There is a positive significant relationship between Foreign Direct Investments (FDI) and manufacturing output of automobile industry.

$\mathrm{H}_{\mathrm{i}}$ There is a positive significant relationship betweenInformation and Communication Technology (ICT) penetration on employment in the automobile industry.

$\mathrm{H}_{\mathrm{i}}$ There is a positive significant relationship between trade openness on capacity utilization in the automobile industry.

\subsection{Limitations of the Study}

The major limitation of the study ischallenge of sourcing of data on the decomposed variablesand also,the researcher was faced with the already known problem of gathering materials for the research. Moreso, time and financial constraintsas it relates with obtaining the needed data for the study all constituted limitations for the study.

\subsection{Conceptual Review}

\section{Review of Related Literature}

Ololade (2014) noted that increasing interdependence of the global economy manifesting in the intertransfer and flows of trade, capital and investment between and among countries of the world is expected to have a far reaching effects on the economic growth of a participating nation through its multiplier effect on such nations manufacturing sector.

However, Hill (2004), recommended a two facets perception of the concept thus, globalization of markets and the globalization of production. According to him, globalisation of production refers to the sourcing of goods and services from locations around the globe to take advantage of national differences in the cost and quantity of factors of production. This global dispersal of productive activities (notably manufacturing) is targeted at lowering 
the overall cost structure of firm's engaging in global production and improve quantity of product. This idea presupposes the integral position of globalisation in the manufacturing process of a nation that engages in openness.

Economic theory predicts that countries that adopt a more open stance towards globalisation enjoy higher growth rates than those that close their economies to trade (Saches and Warner, 1995, Frankel and Romer 1999; Hill 2004, Obadan, 2010). This idea brings to light that openness of an economy to the world economies has with it an unprecedented increased financial and capital flow among other changes that the underconnectivity process.

According to International Monetary Fund (2003), Foreign direct investment (FDI) is defined as an investment involving a long-term relationship and reflecting a lasting interest and control by a resident entity in one economy (foreign direct investor or parent enterprise) in an enterprise resident in an economy other than that of the foreign direct investor (FDI enterprise or affiliate enterprise or foreign affiliate).

FDI implies that the investor exerts a significant degree of influence on the management of the enterprise resident in the other economy. Such investment involves both the initial transaction between the two entities and all subsequent transactions between them and among foreign affiliates, both incorporated and unincorporated. FDI may be undertaken by individuals as well as business entities

Balance of Payment, also known as balance of international payment and abbreviated as BOP refers to the record of all economic transactions between the residents of the country and the rest of the world in a particular period (over a quarter of a year or more commonly over a year). These transactions are made by individuals, firms and government bodies. Thus the balance of payments includes all external visible and non-visible transactions of a country. It represents a summation of country's current demand and supply of the claims on foreign currencies and of foreign claims on its currency (Mathur, Raman \& Dave, 2012).

According toLequiller and Blades (2006), Import consist of transactions in goods and services to a residence of a jurisdiction (such as a nation) from a non-resident while export in international trade refers to selling goods and services produced in the home country to other market.

According to Douglason and Gbosi, (2006), unemployment is the difference between the amount of labour employed at current wage levels and working conditions and the amount of labour not hired at these levels. However he defined employment as a situation in which people who are willing to work at the prevailing wage rate are able to find jobs.

Technology transfer according to Robert (1996), is closely related to innovation. It is the process of transferring skills, knowledge, technologies, methods of manufacturing, samples of manufacturing and facilities among governments, nations, universities and other institutions to ensure that scientific and technological developments are accessible to a wider range of users who can then further develop and exploit the technology into new products, processes, applications, materials or services.

Manpower training is defined as an activity which aims to improve and develop the attitude, behavior skills, and knowledge of employees in accordance with the wishes of the company. Thus, training is meant training in the broad sense, not limited only to developing skills solely (Nitisemito, 1996).

Capacity Utilization is the extent to which a nation or an enterprise actually uses its installed productive capacity. It is the relationship between output that is actually produced with the installed equipment, and the potential output which could be produced with it, if capacity was filly used (Strange, 1981).

Industrial Production is a measure of output of the industrial sector of the economy which includes the manufacturing, mining and utilities ( Strange,1981).

Dembele (1998) put itsucceed when he said that the process of globalisation will tend to consolidate the existing international division of labour which confines African to a role of supplier of raw materials and commodities and consumer of manufactured goods from developed countries.

Ayagi (1990) argued that globalisation led to the creation of parasitic economic relationships and has systematically pushed Nigeria into economic crisis. This dependency culture created and entrenched has thus made Nigeria a country, which does not produce but only consume "So Nigeria imported everything and anything that anybody cared to advertise". With globalisation, Nigeria kept importing at the expense of her own domestic industries. The rule of the game was scrambling and grabbing; everybody was trying to grab what he or she could afford. Foreign companies and interests sponsored and fully partook in the free-for-all scramble for Nigeria's wonderful resources.

Abubakar (2001) contended that the process of globalisation which entails the expansion of capital and market forces into "uncaptured terrain" bring along with it harsh socio-economic condition for the populace. In Nigeria, for instance, the adoption of World Trade Organization (WTO) agreement greatly undermined the living standardof the people and exacerbated the decay in the strategic sectors of the economy. The deterioration in terms of infrastructures diminishes the possibility of enhancing capacity utilization. 
Aina (1996) posits that globalisation depicts the transformation for the relations between states, institutions groups, and individuals, the universalization of certain practices, identities and structures, and perhaps more significantly the expression of the global restructure that has occurred in recent decades in the structure of modern capitalist relations.

Robertson (1992) sees globalisation as the compression and intensification of consciousness of the world as a whole in a way that accelerates a concrete global independence and the consciousness of the global whole. Wang (2004) defines globalisation as the integration of national and regional markets which include the exchange of goods, services, capital and labour in accordance with the objectives principles application to market economy that is, in a comparatively free environment and limited government intervention confined to the rule of law.

Tabb (2008) posits that globalisation is the emergence of a global society in which economic, political, environmental, and cultural events in one part of the world quickly come to have significance for people in other parts of the world.

Friedman (1997) describes globalisation as the integration of creating a single global market and culture. In other words, the activities of nations, (domestic or international, intended or unintended), have implications for other outside its geographical boundaries.

Ohiorhenuan(2000) argued that in the era of globalisation there is an increasing danger of growth actually excluding and dislocating large sections of the population. The 1999 HumanDevelopment Report warned that globalization might actually increase human insecurity and marginalize the poor. The key to development, therefore, is the continuing involvement of each individual in the social and materials conditions of his/her existence as an absolute virtue.

Kwanashie (1999) sees globalisation as a part of the movement of history as evident in certain forces that appear to push for increasing integration of human activities with emphasis in contemporary world focused more on the economic aspect of the process. It is a process of increased integration of national economies of states with the rest of the international system in order to create a more coherent global economy. The process has been increasingly propelled by the revolutionary trend in information technology that combines advancement in computing, electronics and telecommunications which has brought up "a highly dynamic process of storing processing transmitting and present information.

Since the $21^{\text {st }}$ century will essentially be the millennium of technology, information, and knowledge, the present socio-economic conditions of Nigeria suggests that will still have a long way to go in the globalway to go in the global competition of the century. Nigeria's economy is not only dependent on rent derived from all but also extroverted in terms of importation of industrialgoods from western countries. Nigerian's dependence on leading western countries such as the United States, Britain, France and Germany for the importation of goods and services as well as high technology in the oil sector indicates that Nigeria has been firmly entrenched in the global capitalist system (Akinola, 2004). With collapsed infrastructures in health, education, transportation, water supply electricity etc. coupled with the phenomena of "brain chain", Nigeria seems to be marginalized in the contemporary globalized world, (Abubakar, 2001).

From above literature, it is clear that globalisation is associated with some risks and costs, and may have adverse implications for international economic stability. This notwithstanding, it also has its own potential benefits. But for a developing nation like Nigeria, the risks and cost associated with globalisation seem to outweigh its potential benefits.

\subsection{Theoretical Framework.}

This study is anchored ontheory of globalization by Glovanni (2001). The theory is based on the assumption that a greater level of integration is taking place among different countries of the world driven by Trade and Information and Communion Technology(ICT) and that this integration is having an important impact on economic growth and social indicators.

Therefore, globalization of production impact significantly on Nigerian automobile industry in terms of trade openness, Foreign Direct Investment (FDI), Capacity Building, technological advancement, employment and manufacturing output.

Hence, it is imperative for operators in Nigerian automobile sector to leverage on the gains of globalization visa-vise productive resources, equipment, trading product while taking advantage of protectionism polices by the government to competefavourably in the automobile sector.

\subsection{Empirical Review}


Globalization And The Automobile Sector of Nigeria (1990-2015)

A number of scholarly publications are associated with globalisation and the manufacturing sector.Kabiru (2013) examined the challenges brought by globalisation on trade unions. The study uses secondary data and was revealed that globalisation created more vacuum than integration among workers where due to competition postulated by globalisation. Pessoa (2005) study the effects of Foreign Direct Investment (FDI) on the aggregated Total Factor Productivity (TFP) in 16 OECD countries from the period of 1985-2001. By using panel data approach, the empirical test found that Foreign Direct Investment (FDI) has a positive impact on TFP, possibly because FDI is a channel through which technologies are transferred internationally. The result shows that 1 percent increase in FDI, TFP will increase by 0.019 to 0.023 percent. This research finding is supported by other studies findings that similarly obtain FDI have positively and significantly affect growth, in TFP (Nadiri, 1999: Luiz 1999; Girma, 2005; Miyamoto and Lui, 2015; Ng, 2006; Subaran, 2009; and Hong and Sum, 2011).Herzer (2011) examines the long-run relationship between outward FDI and TFP on the 33 samples of developing countries over the period of 1980-2005. Using the techniques of panel co-integration, the results discovered two prominent findings. First, the outward FDIhas a positive effect on the TFP performance indeveloping countries, and, second, the effect is larger in the longrun.

Obidike (2013) whose study focused on finding out the extent to which globalisation and capital account liberalization have supported Nigeria economic development from 1975 to 2008. The study employed Augmented Diekey-Fuller (ADF) to analyze the secondary data collected. The result revealed that capital account and foreign direct investment (FD1) impact positively on real Gross Domestic Product (GDP). The study recommends the target of macroeconomic stability so as to enhance domestic production capacity. On the other hand, Peter's (2006) study investigates the impact of inward FDI on the host country using industry-level data for 11 OECD countries from 1987 to 2003. The results show that the effect of FDI on the productivity is significant and positive, particularly the contribution of capital to productivity, specifically for high-technology industries that use technology intensively. As a results, the larger the FDI, the larger the impact on the productivity in large OECDcountries compared to small OECD countries.

Aminu (2013) investigating the impact of globalisation on the performance of Nigeria economy between 1962 to 2009, adopted simple Annual Average Growth Rate (AAGR) technique for the comparative analysis of growth of key sectors of the Nigeria economy. The study revealed that globalisation has both positive and negative impact on some sector of the economy. The paper therefore recommends concrete effort need to do be taken by government to boost the sectors negatively impacted by globalisation.

Savides and Zachariadis (2005) evaluate the simultaneous contribution of several channels of technology diffusion to the TFP growth performance of the manufacturing sector in low and middle-income group economies. Foreign technology typically has the biggest positive impact on the domestic productivity and value added growth in the manufacturing sector of 32 countries during the period of 1965-1992. Chikeleze (2012) examined the relationship between globalisation and economic development in developing countries. The study uses secondary data and was revealed that developing nations need to come to grips with their membership of the globalized world.Schiff and Wang (2008) examine the impact on TFP growth in the North-South and South-South trade relatedtechnology diffusion and FDI. The findings show that both North-South and South-South trade-research and development have a positive impact on the TFP growth in South and the impact on the TFP of trade-related technology diffusion increases with the level of education in the case of North-South trade, but not in the case of South-South trade.

Ali et al (2012) study the impacts of technology spillovers on the TFP of the manufacturing sector in Pakistan. All manufacturing groups should the presence of both horizontal and vertical spillovers in petroleum and tobacco sector, while it is limited in textile and food subsectors. The results shows that an increase in technology, FDI, imports, and research and development, TFP will also increase. This is similar to Almas and Subal's (2010) findings that technology transfer has appositive impact on the TFP growth in China.

Goldar and Anita (2003) using the industry- level data and incorporating some trade-related variables explicitly conclude that tariff reforms have favourable and significant effects on the TFP growth. Mohamed et al (2005), test the causality between TFP growth and the variables that reflect openness of the economy using panel data in six Tunisian manufacturing subsectors and in OECD countries from the period of 1983 to 1990 . They obtain that the variables of openness of the economy are significant to growth in TF in Tunisian manufacturing sector, while the result is opposite for the OECD countries.

Hwang and Wang (2004) examine the effects of openness to trade on the TFP growth using data from 45 industries of the Japanese manufacturing sector over the period of $1973-1998$. The result exhibit that the openness to trade does not show a positive relation with the growth in TFP. The finding is similar withKim et al's (2007) finding on the study of Korean manufacturing sector from the period 1980 - 2003. 
Globalization And The Automobile Sector of Nigeria (1990-2015)

Another study is supported by Mahadevan's(2002) study that the impact of trade liberalization on the productivity has a positive and significant effect on the technological progress, but it has no significant effect on the technical efficiency in the case of Australian manufacturing industries from 1968 - 69 to $1994-94$.

Chukwudi (2013) writing on the impact of globalisation on performance of Nigeria commercial banks between 2005 to 2010 . The study specifically seeks to determine the effect of foreign private investment, foreign trade and exchange rate in the performance of Nigeria banks. The study utilized panel data econometrics in a pooled regression, where time series and cross- sectional observations were combined and estimated. The study find out that globalisation have positive effect on profit after tax of banks.

Sturgeon (2013) looking at globalization of the automobile industry. Secondary data was sourced. The studies thus conclude that automobile industry, especially firm in the United States, embraced outsourcing without a robust set of industry standards in place for specifying the technical characteristics of products and processes.

Also Nwezeaku (2005) looking at the impact of globalisation on the industrial growth of Nigeria. Secondary data was sourced from World bank journal and multiple regression technique was used to analyze the data. The studies thus conclude that the impact of globalisation on the industrial and economic growth of developing economics has been significant but uneven.

Bello (2014) whose study focused on finding out how globalization channels affect economic growth. The study employed classical least square model to analyse the second data collected. The result revealed that openness and external reserve affect growth negatively whereas foreign exchange rate, average world price and external debt stock affect growth positively. A careful observation of the works of the above scholars reveal that their focus were on the effect of globalisation on trade unions, capital account, economic growth,productivity, commercial banks with no particular reference to the effect of globalization on the automobile subsector of Nigeria. This study therefore seeks to bridge this gap in knowledge by adopting empirical evidence in addition to descriptive analysis through the use of ordinary least square regression techniques to test the relationship between dependent variable(manufacturing output, employment and capacity building) and independent variable (Foreign Direct Investment, Information and Communication Technology and Trade Openness).

\subsection{Overview of Nigeria Automobile Subsector}

In the last couple of years, notably since the global economic downturn in 2008, patronage of the grey import market (Tokumbo market) has grown due to its relatively affordable due to the sharp practices of the grey market dealers who act with near impurity. Practices such as an under declaration of goods and other method to pay lower import duty, have created distortions in the market (Umaru 2009).

The Nigerian automobile market is mainly divided into two categories "New" and "Used". Used cars form a sizable portion of total imports. The new car segment's profit margin is been eroded by the increasing grey import and patronage as the majorly of Nigerians have limited means to buy new vehicle from authorized sources.

The automobile industry in Nigeria dates back to the early 1960s, when private companies pioneered the establishment of local automobile assembly plants using completely/semi knocked-down parts. The federal government became involved in local automobile production 10 years later after concluding agreements with automobile manufactures in Europe installed capacity of 108,000 cars, 56,000 commercial vehicles 10, 000 tractors, $1,000,000$ motorcycles and 1,000,000 bicycles annually, given that the industry works at full capacity, it could provide over 300,000 different jobs, (Nigeria Automobile Council 2009). However, as the country grew into an oil dependent economy in the late 1970s, and the government policy on importation became flexible, automobile manufacturing became difficult and local manufacturing plants could not bear the growing high cost of production, lack of government patronage. As a result, capacity utilization in the automobile industry over the years dropped below expectation with vehicle manufacturing below 10 percent (Yusuf 2010). In order to revive the automobile industry, federal governmentestablished the National Automobile Council (NAC) to ensure the survival and growth of the Nigerian automobile industry using local human and material resources. The overall goal was to enhance the industry's contribution to the national economy.

Unfortunately, due to a number of factors, including the globalisation of the automobile market and the impact of the second hand car imports, the capacity utilization in the subsector, which was $90 \%$ in 1981, is currently $10 \%$ in automobile assembly and $40 \%$ in components manufacture, (Lawa 2010). National Automobile Council (2007) stated that the total vehicular supply (local product plus imports) was over a million units, about $80 \%$ of which were used. There is therefore a scope for new investment in the manufacture of low cost vehicle.

Manufacturing Association of Nigeria (2005) opined that total vehicular import stood at 5,1525 units. In 2002 available records shows that total import as 114,463 as against registered 1, 073, 146 registered numbers in 2002 , it was 223,664 units as against 702,487 registered numbers. 


\subsection{Impacts of Trade Openness on the Nigerian Automobile Sector}

Anyanwu(1997) referred to the manufacturing sector as a sub-set of the industrial sector. According to Chenery and Stout (1996), point out that the impact of trade liberalization on the sector deals with the enlarging the size of the market and the scope of specialization in the manufacturing sector. It also makes a greater use of machinery, encourages investorsand innovations, raiselabour productivity, lower cost and leads to economic development.

Alimi et al, (2011) stress that, the impact of trade openness on the manufacturing in Nigeria also leads to the importation of foreign capital and instill new ideas, technical know-how, skills, managerial talents and entrepreneurship.

Edward (1993), pointed out that the impact of trade openness on the manufacturing sector can be seen on how it has improved the agricultural subsector in the country through the provision of adequate farminput such as improved seeds, fertilizer, tractors for cultivation etc for the supply of new materials to the manufacturing industries. Edward (1998), also stress that the impact of trade openness on the manufacturing sector as fostering healthy competition and checking inefficient exploitative monopolies that are usually established on the grounds of infant industry protection .

\subsection{Impact of Foreign Direct Investment on Nigerian Automobile subsector}

Jerome and Ogunakola (2004) assessed the magnitude, direction and prospects of FDI in Nigeria. They noted that while the FDI regime in Nigeria was generally improving, some serious deficiencies remain. These deficiencies are mainly in the area of the corporate environment such as corporate law, bankruptcy, labour law etc. and institutional uncertainty, as well as rule of law.

Adeolu(2007) opined thatFDI in Nigeria contributes positively to economic growth. Although the overall effect of FDI on economic growth may not be significant, the components of FDI do have a positive impact. He opined that FDI in the communication sector has the highest potential to grow the economy and is in multiples of that of the oil sector. The FDI negatively affect the manufacturing sector, as a result of poor business environment in the country. The level of available human capital is low and there is need for more emphasis on training to enhance its potential to contribute to economic growth.

Adeolu stated that a country inward FDI position is made up of the hosted FDI projects, while outward FDI comprises those investment projects owned abroad.Many countries and continents (especially developing countries) now see attractingFDI as an important element in their strategy for economic development. This is most probably because FDI is seen as an amalgamation of capital,technology, marketing and management.

Sub-Saharan Africa as a region now has to depend very much on FDI for so many reasons, some of which are amplified by Asiedu (2001).

\subsection{Role of Information and Communication Technology (ICT) on automobile Sector of Nigeria}

Abdoulaye, (2011) notedthat Information and Communication Technology (ICT) is the automation of process, controls, and information production using computers, telecommunication, software and ancillary equipment. It is a term that generally covers the harnessing of electronic technology for the information needs of a business at all levels. Themanufacturing subsector has been the subject of a number of recent studies on the contribution of ICT to productivity improvement. A Nigeria MAN study (Manufacturing Association of Nigeria 2004) concluded that in addition to microeconomic reform, new technology, including ICT, has made a much more significant and direct contribution to productivity growth than previously suspected. There are, however, wide disparities in the productivity growth rates of different manufacturing industries and it appear that the less technology oriented and lower capital industries are reading lower productivity growth rates. Other studies have explored the way that firm by changing cultures and work and management practices (National Bureau of statistics 2012). However, relatively little attention has been given in studies of ICT adoption to adoption to developing a holistic view of the role it is being used in their strategies to gain sustainable competitive advantage.

The study has been in the manufacturing industry environment the key ways in which ICT can increase productivity are through its capacity to reduce costs, increase the capability of machinery, and provide increased flexibility in production planning and scheduling. ICT allows for increased scaled and speed of machinery operations as well as an expended management span of control/coordination increased capability comes about the 
digital control hardware embedded in the machinery and the process execution systems and control factory operations.

\subsection{Overview of Nigerian Manufacturing Sector}

Since a peak of $7.83 \%$ in 1982, the contribution of manufacturing as a share of total economic output in Nigeria generally declined (Suleman, 2012). Many factor have contributed to the variation in sector share through time, many of which show both the vulnerability of manufacturing to global economic pressures, as well as the impacts that policy changes can have in reshaping the sector.

Prior to the oil boom of the 1970 's, manufacturing contributed approximately $10 \%$ to Nigeria's economic output. Thereafter, increased revenues from oil caused the sectors relative Gross Domestic Product (GDP) share to decline; growth persisted albeit at a slower rate (Chete, 1996).

Oguchi (2008) noted that recession caused by the fall in oil prices in the early 1980's triggered policy attention to turn back to the manufacturing sector, with steel production gaining prime focus. Prior to this, the Nigerian Enterprises Promotion Degrees of 1972 and 1977 had switched the majority firm ownership from foreign to Nigerian, restricting foreign capital inflows. The lack of affordability of imported goods, combined with the absence of foreign capital and technology encouraged domestic production of base commodities such as soap and salt.

Mita (2010) opined that price manipulation through export and import subsidies encouraged the importation of intermediary inputs and thus the expansion of assembly based industry. A brief spike in manufacturing output was observed in the early 1980 's so that it contributed to $7.83 \%$ of total economic output.

In 1987 import bans on raw materials were imposed under the World Bank Structural Adjustment Programme (SAPs), encouraging import substitution. Intermediary input manufacturers werefewer plant closures. This combined with the privatization and commercialization Act of 1988, encouraged a higher degree of efficiency to be achieved in manufacturing. Adamu (2012) stated that throughout the 1990s and 2000's, Nigeria continued to rely heavily on the export of oil, allowing manufacturing to remain in decline. Firms were not export orientated, and lackedefficiency causing competitive companies to relocate factories, such as beverages, textiles, cement and tobacco kept the sector afloat, but even these operated at under half of their capacity. To this day, production is mainly located in Lagos and its periphery, and to a lesser extent some other commercial towns such as Kano or Kaduna.

\subsection{The Evolution of Globalisation}

Globalisation involves the interplay of market, technology and state, which are amongst the oldest and most distinctive human innovations. Exchange, the fundamental principle on which market is organized, is known to exist in the most primitive human societies. Man is not the only living creatures with the ability to store surpluses and live in complex societies controlled by chiefs consider the industrious ant and bees, but he is unique in his ability to socially redistribute these surpluses through measuring by complex divisions of labour under the authority of the state.

The saga of globalisation is that of an unbound Prometheus, with surges in productivity and growth unparalleled in history as markets, technology and states are progressively freed from local demand and supply constraints. Although the term "globalisation" has gained currency only recently, the forces driving this trend can be traced back to the end of the middle Ages in Europe.

Pre-modern societies, however, were above all else defined by localism and decentralization. Most people remained at their place of birth right through their lives. Migration was a one-way street to resettle in VirginTerritory in response to conquest, calamity or local demographic pressure. Religious experience was mostly limited to the local perish, with wider pilgrimages limited to a select few. Empires meant mostly march of armies over land, and were never transcontinental, with the notable exception of North African adjoining the Mediterranean. State power was a coalition of local power elites owing allegiance to a monarch who never had access to centralized administrative machinery.

The second phase from the late eighteenth century was marked by the spread of the Industrial Resolution and vast improvements in human technology, inanimate traction, productivity and demand, which led to mass production and conveyance of merchandise goods and people, cross border integration through bulk long-distance trade, investments flows and empire during a phase of European imperial expansion which saw the flag follow trade across the globe. 
During the third phase, merchandise trade resumed its triumphant march as the engine of hyper growth in East Asia from the 1970s. International trade/GDP ratios recovered to their late $19^{\text {th }}$ century level by the last decade the second phase in the nineteenth century involved, in the main, the export of mass- produced merchandise to the colonies; this time round the export dynamism came from the erstwhile colonies. This globalisation thrust was led by transnational corporations (TNCs) that endeavored to disseminate international trade and modern technology to every flag on earth.

Globalisation arguably entered a frenetic fourth phase from the end of the twentieth century in which developed and developing countries are becoming more equal partners in the flow of cross border trade and investment, as per capita income between the developed world and the developing world rapid converge, gal vanished by the awakening of the ancient sleeping giants, China and India.

\subsection{Emergence of Global Institutions}

Over the past half century, a number of important global institutions have been created to help perform these functions, including the General Agreement on Tariffs and Trade (GATT) and its successor, the World Trade Organization (WTO); the International Monetary Fund (IMF) and its sister institution, the World Bank;

The World Trade Organization (Like the GATT before it) is primarily responsible for policing the world trading system and making sure nation-states adhere to the rules laid down in trade treaties signed by WTO member states. As of 2007, 150 nations that collectively accounted for 97 percent of world trade were WTO members, thereby giving the organization enormous scope and influence. The WTO is also responsible for facilitating the establishment of additional multinational agreements between WTO member states. Over its entire history, and that of the GATT before it, the WTO has promoted lowering barriers to cross-border trade and investment.

The International Monetary Fund and the World Bank were both created in 1944 by 44 nations that met at Bretton Woods, New Hamphire. The 1MF was established to maintain order in the International Monetary System; the World Bank was set up to promote economic development. The World Bank is the less controversial of two sister institutions. It has focused on making low-interest loan to cash strapped governments in poor nations that wish to undertake significant infrastructure investments such as building dam or roads. The IMF is often seen as the lender of last resort to nation-states whose economics are in turmoil and currencies are losing value against those of other nations.

\subsection{Drivers of Globalisation}

The media and almost every book on globalisation and international business speak about different drivers of globalisation and they can basically be separated into five different groups;

1. Technological Drivers: technology shaped and set the foundation for modern globalisation. Innovations in the transportation technology revolutionized the industry. The most important developments among these are the commercial jet aircraft and the concept of containerization in the late 1970s and 1980s. Inventions in the area of microprocessor and telecommunications enabled highly effective computing and communication at a low-cost level. Finally the rapid growth of the interest is the latest technological driver that created global e-business and e-commerce.

2. Political Drivers: Liberalized trading rules and deregulated markets lead to lowered tariffs and allowed foreign direct investments in almost all over the world.

3. Market Drivers: As domestic markets become more and more saturated, the opportunities for growth are limited and global expanding is a way most organizations chose to overcome this situation.

4. Cost Drivers: Sourcing efficiency and costs vary from country to country and global firms can take advantage of this fact. Other cost drivers to globalisation are the opportunity to build global scale economics and the high product development costs nowadays.

5. Competitive Drivers: With the global market, global inter-firm competition increases and organizations are forced to "play" international. Strong interdependences among countries and high two way trades and FDI actions support these drivers.

\subsection{Effect of Globalisation on Nigerian Manufacturing Subsector}

Globalisation is a dual sided phenomenon which has been beneficial to many countries and has not helped matters in the same or many other countries especially the developing countries. This is so because most developing countries have very weak capacities to take advantages of global markets as they are still grappling with the provision of basic necessities such as roads, railways food, and water among others. In the absence and inadequate 
of these basic necessities, it becomes difficult to fully utilize the opportunities and benefits of globalisation in the developing countries even in Nigeria.

By integrating the world into a global economy through trade liberalization, commercialization and privatization, globalisation in one aspect undermine growth in the manufacturing subsector in Nigeria as it exposes local firms and industries to competition from global corporation who often have better financing, technology, advertising and market reach. With increasing breakdown of barriers in developing countries including Nigeria as a result of globalisation industrialized nations have therefore taken advantages of trade liberalization thereby seeking market to dump their cheap manufactured goods and rendering the local industries as the demand for goods produced in the country decline due to low output of the local industries as the demand for goods produced in the country decline due to cheap imported goods and high cost of production faced by the industries. With globalisation, Nigeria kept importing everything at the expense of her own domestic industries. These problems have therefore caused firms to leave their industries rendering many Nigeria unemployed.

Trade liberalization, a major policy thrust in the Structural Adjustment Programme (SAP) in 1986 in Nigeria led to the exposure of infant local industries in Nigeria to unfavourable competition with Multinational Corporation (MNCs). The local industries do not have what it takes to complete with these multinational corporations which have stronger financial base, produce better and cheaper products and have a strong and efficient managerial capacity. Trade liberalization focused exclusively on import liberalization without sufficient attention to improving export markets access and establishing a competitive exchange rate to ensure that the resources freed-up in the import-competing subsector are deployed into the export sector.

The domestic industry is faced withunfavourable competition with the influx of cheap finished products and the dumping of sub-standard goods from industrialized and other developing nations. These problems are still prominent in the sector as the manufacturing sector contribute an animal average of $9.50 \%$ in the 1981-1985, 7.08\% from 1991-1995 and 4.95\%, 3.9\% and 2.6\% during the periods 1996-1999, 2000-2003 and 2004-2007 respectively to the cross domestic predict (GDP). The manufacturing subsector in spite of its huge potentials to create wealth reduce poverty and generate employment has remained stagnant contributing $3.31 \%$ annually on the average to GDP in the period 1998-2008. The stagnation and unimpressive performance of this sub-sector is injurious to the industries subsector and a major obstacle facing the growth and development of the Nigeria economy.

Another problem faced by the Nigeria manufacturing subsector in the liberalization process is that Nigeria may be able to control how far she can open her borders but cannot determine how other countries open there. Thus, increased trade barriers by developed countries have however served as an obstacle in promoting manufacturing goods export in the country.

\subsection{Summary of Review of Related Literature}

The studies engage on extensive review of literature on the implications of globalisations on manufacturing subsector of Nigeria. The study looked at various expert opinions on the concept of globalization by different scholars. In the same vein, the study looked at overview of Nigerian manufacturing sector, automobile sector, impact of trade openness overview of automobile subsector, impact foreign direct investment (FDI), role of Information and Communication Technology (ICT) penetration, evolution of globalization, emergence of global institution, driver of globalization and effect of globalization on Nigeria manufacturing sector.

Furthermore, the study reviewed empirically the works of the following scholars. Kabiru (2013) examined the challenges brought by globalisation on trade unions. Obidike (2013) whose study focused on finding out the extent to which globalisation and capital account liberalization have supported Nigeria economic development from 1975 to 2008. Chukwudi(2013)writing on the impact of globalisation on performance of Nigeria commercial banks between 2005 to 2010. A careful observation of the works of the above scholars reveal that their focus were on the effect of globalisation on trade unions, capital account, economic growth, productivity, commercial banks with no particular reference to the effect of globalization on the automobile subsector of Nigeria. This study therefore seeks to bridge this gap in knowledge by adopting empirical evidence in addition to descriptive analysis through the use of ordinary least square regression techniques to test the relationship between dependent variable (manufacturing output, employment and capacity building) and independent variable (Foreign Direct Investment, Information and Communication Technology and Trade Openness). 


\subsection{Research Design}

\section{Methods}

Research design encompasses the methodology and methods employed to conduct scientific research. It is against this background that this study seeks to adopt correlational research design. This research design seeks to establish what relationship exists between two or more variables. Usually such studies indicate the direction and magnitude of relationship between the variables (Nworgu, 2006).

\subsection{Sources of data Collection}

Secondary data was used for this study. This includes data from Central Bank of Nigeria Statistical Bulletin, National Bureau of Statistics, Library, Internet, Newspapers, Articles, Journals, Textbooks, Publications from automobile industries, and World Bank publications.

\subsection{Model Specifications}

3.3.1Manufacturing Output Equation: this equation seeks to examine the extent of relationship between Foreign Direct Investment(FDI)and manufacturing output of automobile industries.

$\mathrm{MOT}=\mathrm{f}(\mathrm{FDI}, \mathrm{IMP}, \mathrm{EXP}, \mathrm{BOP}) e_{t}$

This can be econometrically thus;

$\mathrm{MOT}=\mathrm{a}_{0}+\mathrm{a}_{1} \mathrm{LFDI}+\mathrm{a}_{2} \mathrm{LIMP}+\mathrm{a}_{3} \mathrm{LEXP}+\mathrm{a}_{4} \mathrm{LBOP}$

Where:

$e_{t}-$ Represents Stochastic Term

$a_{0}-\mathrm{a}_{4}$ are Parameter Estimate

LMOT $=$ Log of Manufacturing Output

LFDI $=$ Log of Foreign Direct Investment

LIMP $=$ Log of Import

LEXP $=$ Log of Export

LBOP $=$ Log of Balance of Payment

The variables used in the study include;

Manufacturing output is a measure of the performance of the manufacturing sector.Manufacturing output is the total inflation adjusted value of output produced by automobile industries.

Foreign Direct Investment is investment undertaken by an enterprise that is either whole or partly foreign owned. Data on foreign private investment collected by the Central Bank of Nigeria Survey of enterprises will be used to measure foreign direct investment.Foreign Direct Investment plays a critical role in automobile industries.

(BOP) is defined as a systematic record of economic and financial transactions for a given period between residents of an economy and no-residents (the rest of the word).

Employment is an economic indicator that refers to the number or proportion of people in an economy who are willing and able to work. An efficient and vibrant automobile subsector will absorb highly skilled personnel that are not employed. The automobilesector if properly develop, will be the largest employer of labour and reduced unemployment rate in Nigeria.

3.3.2 Employment Equation: This equation seeksto ascertain the value added byInformation and Communication Technology(ICT)penetrationon employment in the automobile sector in Nigeria.

$\mathrm{EMP}=\mathrm{f}(\mathrm{FDI}, \mathrm{TT}, \mathrm{MANT}, \mathrm{SOL}) e_{t}$

This can be econometrically thus;

EMP $=b_{0}+b_{1}$ LFDI $+b_{2}$ LTT $+b_{3}$ LMANT $+b_{4}$ LSOL $+b_{5}$ INDP -- (ii)

Where;

$\mathrm{e}_{\mathrm{t}} \quad=$ Represents Stochastic Term.

$\mathrm{b}_{0}-\mathrm{b}_{5}=$ are Parameter Estimate.

LEMP $=$ Log of Employment

LFDI $=$ Log of Foreign Direct Investment

LTT $=$ Log of Technology Transfer 
LMANT $=$ Log of Manpower Training

LSOL $=$ Log of Standard of Living

LINDP $=$ Log of Industrial Production

The variables used in the study include;

Manufacturing entails the process of converting raw materials components or parts into finished goods that meet a customer's expectations or specifications. Manufacturing is key component in automobile subsector. Manufacturing in automobile sector involves design, predict review, and process planning.

Industrial Production is a measure of output of the industrial sector of the economy industrial sector of the economy. Industrial production leads to increase in output both in quantity and quality in automobile sector as evident in different design in terms of efficiency and durability in automobile sector.

3.3.3Capacity Utilization Equation:This equation seeks to determine the influence of Trade Openness on capacity building in the automobile industry.

$\mathrm{CU}=\mathrm{f}(\mathrm{TT}, \mathrm{INDP}, \mathrm{TO}) e_{t}$

This can be econometrically thus,

$\mathrm{CB}=\mathrm{c}_{0}+\mathrm{c}_{1} \mathrm{LTT}+\mathrm{c}_{2} \mathrm{LINDP}+\mathrm{c}_{3} \mathrm{LTO}$

Where;

$\mathrm{e}_{\mathrm{t}} \quad=$ Represent Stochastic Term.

$\mathrm{c}_{0}-\mathrm{c}_{3}=$ are parameter Estimate.

$\mathrm{LCU}=\mathrm{Log}$ of Capacity Utilization

LTT $=$ Log of Technology Transfer

LINDP $=$ Log of Industrial Production

TO $\quad=$ Trade Openness

The variable used in the study include;

Capacity utilization entails the extent or level to which the productive, capacity of a plant, firm, or country is being used in generation of goods and service. It enhances effective and efficient utilization of manufacturing and resources in automobile plant.

\subsection{Data Required}

The following data will be used for the study;

Data on Manufacturing outputfor the period of 26 years.

Data on Import for the period of 26 years.

Data on Export for the period of 26 years.

Data on BOP for the period of 26 years.

Data on Technology Transfer for the period of 26 years.

Data on Manpower Training for the period of 26 years.

Data on Standard of Living for the period of 26 years.

Data on Employment for the period of 26 years.

Data on Capacity Utilization for the period of 26 years.

Data on Foreign Direct Investment for the period of 26 years.

Data on trade opennessfor the periodof 26 years.

Data on Industrial Production for the period of 26 years.

\subsection{Summary of Complete Equation}

MOT $=a_{0}+a_{1}$ LFDI $+\mathrm{a}_{2}$ LIMP $+\mathrm{a}_{3} \mathrm{LEXP}+\mathrm{a}_{4} \mathrm{LBOP}+e_{t}$----------- (i)

EMP $=b_{0}+b_{1}$ LFDI $+b_{2}$ LTT $+b_{3}$ LMANT $+b_{4}$ LSOL $+b_{5}$ LINDP $+e_{t^{---}}$(ii)

$\mathrm{CU}=\mathrm{c}_{0}+\mathrm{c}_{1} \mathrm{LTT}+\mathrm{c}_{2} \mathrm{LINDP}+\mathrm{c}_{3} \mathrm{LTO}+e_{t}$

\subsection{Structure of the Parameter Estimate}

$a_{0}-\mathrm{a}_{3}=$ Manufacturing Output --

$b_{0}-b_{5} \quad=$ Employment -

$\mathrm{c}_{0}-\mathrm{c}_{3} \quad=$ Capacity Utilization--

\subsection{Method of Data Analysis}


The study utilized the Ordinary Least Square (OLS) method of analysis. This statistical tool seeks to establish the strength or degree of association between the dependent and independent variables. EVIE7 econometric package was be used for the analysis.

\subsection{Data Presentation}

\section{Data Presentation And Analysis}

This chapter presents the data involved in analyzing the information below for the study. The data is meant for empirical investigation. Here, regression was run so as to be equipped for the interpretation and also to provide solutions to the research questions in respect to Globalization and automobile sector in Nigeria. The first column in the table 4.1a below represents the number of years considered in the study, the second to the fourth column, which are the independent variables and dependent variable represents Manufacturing Output, Foreign Direct Investments, Information and Communication Technology Penetration and Trade Openness for each year of the considered duration.

Table 4.1a: Manufacturing Output Equation

$\mathrm{MOT}=\mathrm{f}(\mathrm{FDI}, \mathrm{IMP}, \mathrm{EXP}, \mathrm{BOP}) e_{t}$

Foreign Direct Investments and Manufacturing Output in Nigeria (1990 -2015)

\begin{tabular}{|l|l|l|l|l|l|}
\hline YEAR & MOT & BOP & FDI & IMP & EXP \\
\hline 1990 & 102.4000 & 18498.2 & 6916.1 & 45717.9 & 405.5 \\
\hline 1991 & 117.4000 & 5959.6 & 14463.1 & 89488,2 & 472 \\
\hline 1992 & 132.8000 & 65271.8 & 29675.2 & 143151.2 & 244.4 \\
\hline 1993 & 94.80000 & 13615.9 & 75940.6 & 165629.4 & 227.8 \\
\hline 1994 & 83.40000 & 42623.3 & 111299 & 162788.8 & 244.4 \\
\hline 1995 & 100.0000 & 195316.3 & 110452.7 & 755127.7 & 285.7 \\
\hline 1996 & 96.1000 & 53152 & 110456.7 & 562626.6 & 927.57 \\
\hline 1997 & 128.4000 & 38076.3 & 80750.4 & 845716.6 & 128.62 \\
\hline 1998 & 135.2000 & 220675.1 & 92792.5 & 837418.7 & 121.25 \\
\hline 1999 & 154.3000 & 326634.3 & 115952.2 & 863515.7 & 117.79 \\
\hline 2000 & 162.9000 & 314139,2 & 132481 & 985022.4 & 116.95 \\
\hline 2001 & 178.1000 & 24738.7 & 252248 & 1358180.3 & 192.09 \\
\hline 2002 & 169.200 & 563483.9 & 374937.7 & 1512695,3 & 183.98 \\
\hline 2003 & 145.2000 & 162298.4 & 417175.4 & 2080235.3 & 164.94 \\
\hline 2004 & 144.200 & 1124157.2 & 455316 & 1987045.3 & 299.31 \\
\hline 2005 & 136.2000 & 1362253.9 & 415809.7 & 2800856.3 & 448.95 \\
\hline 2006 & 138.7000 & 1772650.9 & 429433.7 & 3108519.3 & 714.06 \\
\hline 2007 & 138.5000 & 1666525.4 & 433519.8 & 3911952.6 & 718.11 \\
\hline 2008 & 133.1000 & 992282.3 & 431476.7 & 5189802.6 & 795.04 \\
\hline 2009 & 133.1000 & 1862597.8 & 4322498.2 & 5102534.4 & 968.02 \\
\hline 2010 & 133.7000 & 305561.31 & 4376.98 & 7614440.5 & 881.53 \\
\hline 2011 & 138.2000 & 831406.39 & 449501.6 & 10237453 & 924.77 \\
\hline 2012 & 142.2000 & 1949196.9 & 415609.7 & 8342000.2 & 903.15 \\
\hline 2013 & 146.3000 & 1209069.8 & 421436.7 & 8012000.4 & 913.96 \\
\hline 2014 & 148.0000 & 2046779 & 459501.5 & 21250120 & 933.87 \\
\hline 2015 & 145.5 & 1735015.2 & 432182.6 & 12534706.9 & 917 \\
\hline
\end{tabular}

Source: Central Bank of Nigeria Statistical Bulletin (various issues)

National Bureau of Statistics

\section{KEYS}

MOT = Manufacturing Output

FDI $=$ Foreign Direct Investment

$\mathrm{BOP}=$ Balance of Payment

IMP = Import

$\mathrm{EXP}=$ Export

Table 4.1b: Employment Equation

$\mathrm{EMP}=\mathrm{f}(\mathrm{FDI}, \mathrm{TT}, \mathrm{MANT}, \mathrm{SOL}, \mathrm{INDP}) e_{t}$

Information and Communication Technology Penetration and Employment in Nigeria (1990-2015)

\begin{tabular}{|l|l|l|l|l|l|l|}
\hline YEAR & EMP & FDI & TT & MANT & INDP & SOL \\
\hline
\end{tabular}


Globalization And The Automobile Sector of Nigeria (1990-2015)

\begin{tabular}{|l|l|l|ll|l|l|l|}
\hline 1990 & 99934 & 6916.1 & & 23 & 653.5 & 162.9 & 31.6 \\
\hline 1991 & 123137 & 14463.1 & 116 & 1084.1 & 178.1 & 36.4 \\
\hline 1992 & 97349 & 29675.2 & 277 & 1941.8 & 169.5 & 31.3 \\
\hline 1993 & 183540 & 75940.6 & 240 & 2294.6 & 145.5 & 31.6 \\
\hline 1994 & 100400 & 111299 & & 131 & 1554.2 & 144.2 & 36.4 \\
\hline 1995 & 114672 & 110452.7 & 276 & 2060.4 & 136.2 & 31.3 \\
\hline 1996 & 152593 & 110456.7 & 218 & 7999.1 & 138.7 & 31.6 \\
\hline 1997 & 184103 & 80750.4 & 308 & 10283.8 & 138.5 & 36.4 \\
\hline 1998 & 149693 & 92792.5 & 294 & 12728.7 & 133.1 & 54 \\
\hline 1999 & 190328 & 115952.2 & 181 & 15351.8 & 137.7 & 54 \\
\hline 2000 & 170287 & 132481 & 116 & 15944.0 & 142.2 & 65.4 \\
\hline 2001 & 180311 & 252248 & 141 & 26721.3 & 146.3 & 65.3 \\
\hline 2002 & 180309 & 374937.7 & 132 & 31563.8 & 148 & 66.3 \\
\hline 2003 & 180308 & 417175.4 & 93 & 67568.1 & 145.7 & 66.5 \\
\hline 2004 & 176960 & 455316 & 95 & 59744.6 & 145.8 & 67.3 \\
\hline 2005 & 179196.3 & 415809.7 & 98 & 109455.2 & 145.9 & 71.2 \\
\hline 2006 & 178824.7 & 429433.7 & 70 & 79436.1 & 145.8 & 76.4 \\
\hline 2007 & 178330 & 433519.8 & 67 & 93767.9 & 145.8 & 73.2 \\
\hline 2008 & 178783.7 & 431476.7 & & 87 & 94219.7 & 145.8 & 77.6 \\
\hline 2009 & 178646.1 & 4322498.2 & 79 & 89141.2 & 145.8 & 67.6 \\
\hline 2010 & 178586.6 & 4376.98 & 90 & 92376.2 & 145.8 & 73.4 \\
\hline 2011 & 178672.1 & 449501.6 & 83 & 90758.7 & 145.8 & 76.5 \\
\hline 2012 & 178629.3 & 415609.7 & & 146 & 91660.3 & 145.8 & 78.1 \\
\hline 2013 & 178650.7 & 421436.7 & 149 & 91598.4 & 145.8 & 76 \\
\hline 2014 & 178640 & 459501.5 & 170 & 91339.1 & 145.8 & 73.9 \\
\hline 2015 & 178640 & 432182.6 & 155 & 91532.6 & 145.8 & 76 \\
\hline
\end{tabular}

Source: Central Bank of Nigeria Statistical Bulletin (various issues) National Bureau Statistics

\section{KEYS}

$\mathrm{EMP}=$ Employment

FDI $=$ Foreign Direct Investment

ICTP = Information and Communication Technology Penetration

$\mathrm{SOL}=$ Standard of Living

INDP = Industrial Production

MANT $=$ Manpower Training

TT $=$ Technology Transfer

Table 4.1c: Capacity Building Equation

$\mathrm{CU}=\mathrm{f}(\mathrm{TO}, \mathrm{CAPU}, \mathrm{INDP}) e$ (i)

Trade Openness and Capacity Utilization in the automobile industry in Nigeria (1990-2015)

\begin{tabular}{|c|c|c|c|c|}
\hline YEAR & CAPU & TT & INDP & TO \\
\hline 1990 & 52 & 23 & 162.9 & 0.469096 \\
\hline 1991 & 52.8 & 116 & 178.1 & 0.501114 \\
\hline 1992 & 52.7 & 277 & 169.5 & 0.386737 \\
\hline 1993 & 52.6 & 240 & 145.5 & 0.308928 \\
\hline 1994 & 52.5 & 131 & 144.2 & 0.272822 \\
\hline 1995 & 52.4 & 276 & 136.2 & 0.276594 \\
\hline 1996 & 52.3 & 218 & 138.7 & 0.215544 \\
\hline 1997 & 52.2 & 308 & 138.5 & 0.458287 \\
\hline 1998 & 52.2 & 294 & 133.1 & 0.37844 \\
\hline 1999 & 52 & 181 & 137.7 & 0.409744 \\
\hline 2000 & 52 & 116 & 142.2 & 0.581588 \\
\hline 2001 & 51.8 & 141 & 146.3 & 0.676055 \\
\hline 2002 & 51.1 & 132 & 148 & 0.654132 \\
\hline 2003 & 51.2 & 93 & 145.7 & 0.562095 \\
\hline 2004 & 51 & 95 & 145.8 & 0.409893 \\
\hline 2005 & 50.6 & 98 & 145.9 & 0.856301 \\
\hline 2006 & 50.8 & 70 & 145.8 & 0.692699 \\
\hline 2007 & 50.9 & 67 & 145.8 & 0.744968 \\
\hline 2008 & 51 & 87 & 145.8 & 0.642289 \\
\hline 2009 & 51.3 & 79 & 145.8 & 0.645874 \\
\hline 2010 & 51.4 & 90 & 145.8 & 0.688475 \\
\hline 2011 & 51.1 & 83 & 145.8 & 0.603159 \\
\hline 2012 & 51.1 & 146 & 145.8 & 0.743848 \\
\hline
\end{tabular}




\begin{tabular}{|l|l|l|l|l|}
\hline 2013 & 51.3 & 149 & 145.8 & 0.577495 \\
\hline 2014 & 51.3 & 170 & 145.8 & 0.743848 \\
\hline 2015 & 51.2 & 155 & 145.8 & 0.688397 \\
\hline
\end{tabular}

Source: Central Bank of Nigeria Statistical Bulletin (various issues)National Bureau Statistics

\section{KEYS}

TT $=$ Technology Transfer

CAPU $=$ Capacity Utilization

INDP = Industrial Production

$\mathrm{TO}=$ Trade Openness

\subsection{Presentation of Results}

The model specified in the previous chapter can be referred to as Multiple Regression Model since it contains dependent and independent variables, as well as, unknown parameters to be estimated. Using Ordinary Least Square Regression approach and with the aid of EVIEW7 software for Econometric modeling, we have the following output for the models;

Table 4.2a: Regression Result of the extent of relationship between Foreign Direct Investments on Manufacturing

Dependent Variable: MOT

Output of automobile industry in Nigeria.

Method: Least Squares

Date: 02/02/16 Time: 09:54

Sample: 19902015

Included observations: 26

\begin{tabular}{|l|l|l|l|l|}
\hline Variable & Coefficient & Std. Error & t-Statistic & Prob. \\
\hline C & 131.9223 & 8.501119 & 15.51823 & 0.0000 \\
\hline FDI & $1.21 \mathrm{E}-06$ & $6.03 \mathrm{E}-06$ & 0.200517 & 0.0433 \\
\hline IMP & $-1.93 \mathrm{E}-06$ & $1.36 \mathrm{E}-06$ & 1.418061 & 0.0133 \\
\hline EXP & 0.034950 & 0.020362 & -1.716379 & 0.9033 \\
\hline BOP & $1.27 \mathrm{E}-05$ & $9.30 \mathrm{E}-06$ & 1.367601 & 0.0183 \\
\hline R-squared & 0.799739 & \multicolumn{2}{|l|}{ Mean dependent var } & 131.6696 \\
\hline Adjusted R-squared & 0.744126 & S.D. dependent var & 22.15338 \\
\hline S.E. of regression & 20.49486 & Akaike info criterion & 9.067886 \\
\hline Sum squared resid & 7560.708 & Schwarz criterion & 9.314732 \\
\hline Log likelihood & -99.28068 & Hannan-Quinn criter. & 9.129967 \\
\hline F-statistic & 1.926177 & Durbin-Watson stat & 0.746475 \\
\hline Prob(F-statistic) & 0.149715 & \multicolumn{2}{|l}{} \\
\hline
\end{tabular}

\begin{tabular}{|l|l|l|l|l|l|}
\hline & BOP & EXP & FDI & IMP & MOT \\
\hline Mean & 743513.6 & 509.6446 & 407546.3 & 4120690. & 133.7654 \\
\hline Median & 326634.3 & 427.2250 & 313592.9 & 2033640. & 137.2000 \\
\hline Maximum & 2046779. & 968.0200 & 4322498. & 21250120 & 178.1000 \\
\hline Minimum & 5959.600 & 116.9500 & 4376.980 & 45717.90 & 83.40000 \\
\hline Std. Dev. & 749081.9 & 333.8448 & 817867.5 & 5097859. & 23.03934 \\
\hline Skewness & 0.514225 & 0.197650 & 4.438733 & 1.848288 & -0.464286 \\
\hline Kurtosis & 1.653729 & 1.312508 & 21.85623 & 6.384885 & 2.886624 \\
\hline Jarque-Bera & 2.989744 & 3.254214 & 470.5640 & 25.12212 & 0.948025 \\
\hline Probability & 0.224277 & 0.196497 & 0.000000 & 0.000004 & 0.622499 \\
\hline Sum & 18587840 & 13250.76 & 10596204 & 98896562 & 3477.900 \\
\hline Sum Sq. Dev. & $1.35 \mathrm{E}+13$ & 2786308. & $1.67 \mathrm{E}+13$ & $5.98 \mathrm{E}+14$ & 13270.28 \\
\hline Observations & 26 & 26 & 26 & 26 & 26 \\
\hline
\end{tabular}

Model is significant at 0.05 per cent which implies the model is adequate and can be used for decision making. In the test of significant of parameters in the model using t-test, the p-values of parameters are less than 0.05 per cent except that of EXP which is greater than 0.05 per cent. The p-values of t-test imply all parameters in the model are significant except EXP. The coefficient of determination (R-Square) of the model is 79 per cent which implies the independent variables contributed up to 70 per cent to the fluctuation of the dependent variable. 
Table 4.2b: Regression result for the value added by Information and Communication Technology (ICT) Penetration on Employment in the automobile industry in Nigeria

Dependent Variable: EMP

Method: Least Squares

Date: 02/02/16 Time: 10:17

Sample: 19902015

Included observations: 26

\begin{tabular}{|c|c|c|c|c|c|c|}
\hline \multicolumn{2}{|l|}{ Variable } & Coefficient & Std. Error & \multicolumn{2}{|l|}{ t-Statistic } & Prob. \\
\hline \multicolumn{2}{|l|}{$\mathrm{C}$} & 208729.2 & 93572.10 & 2.230678 & \multicolumn{2}{|c|}{0.0373} \\
\hline \multicolumn{2}{|l|}{ FDI } & 0.002248 & 0.005467 & 0.411113 & & 0.0354 \\
\hline \multicolumn{2}{|l|}{ INDP } & -837.2237 & 506.5505 & -1.652794 & & 0.0040 \\
\hline \multicolumn{2}{|l|}{ MANT } & -0.026411 & 0.227332 & -0.116179 & & 0.9087 \\
\hline \multicolumn{2}{|l|}{ SOL } & 1189.659 & 535.8758 & 2.220028 & & 0.0381 \\
\hline \multicolumn{2}{|l|}{$\mathrm{TT}$} & 55.50812 & 72.80556 & 0.762416 & & 0.0547 \\
\hline \multirow{7}{*}{\multicolumn{2}{|c|}{$\begin{array}{l}\text { R-squared } \\
\text { Adjusted R-squared } \\
\text { S.E. of regression } \\
\text { Sum squared resid } \\
\text { Log likelihood } \\
\text { F-statistic } \\
\text { Prob(F-statistic) }\end{array}$}} & 0.621092 & \multirow{7}{*}{\multicolumn{2}{|c|}{$\begin{array}{l}\text { Mean dependent var } \\
\text { S.D. dependent var } \\
\text { Akaike info criterion } \\
\text { Schwarz criterion } \\
\text { Hannan-Quinn criter. } \\
\text { Durbin-Watson stat }\end{array}$}} & & \multirow{7}{*}{$\begin{array}{l}163443.2 \\
29584.19 \\
22.87972 \\
23.17005 \\
22.96333 \\
2.768067\end{array}$} \\
\hline & & 0.526365 & & & 295 & \\
\hline & & 20360.18 & & & 22 . & \\
\hline & & $8.29 E+09$ & & & 23. & \\
\hline & & -291.4364 & & & 22. & \\
\hline & & 6.556649 & & & 2.7 & \\
\hline & & 0.000919 & & & & \\
\hline & EMP & FDI & INDP & MANT & SOL & TT \\
\hline ean & 163443.2 & 407546.3 & 146.7808 & 48953.05 & 58.66538 & 147.5000 \\
\hline edian & 178640.0 & 313592.9 & 145.8000 & 45654.20 & 66.40000 & 131.5000 \\
\hline aximum & 190328.0 & 4322498 & 178.1000 & 109455.2 & 78.10000 & 308.0000 \\
\hline inimum & 97349.00 & 4376.980 & 133.1000 & 653.5000 & 31.30000 & 23.00000 \\
\hline d. Dev. & 29584.19 & 817867.5 & 9.624677 & 41263.83 & 18.30508 & 77.52225 \\
\hline cewness & -1.399375 & 4.438733 & 1.872231 & 0.039058 & -0.554193 & 0.730803 \\
\hline urtosis & 3.325538 & 21.85623 & 6.592682 & 1.216256 & 1.598756 & 2.515653 \\
\hline rque-Bera & 8.600552 & 470.5640 & 29.17239 & 3.453497 & 3.458006 & 2.568457 \\
\hline obability & 0.013565 & 0.000000 & 0.000000 & 0.177862 & 0.177461 & 0.276864 \\
\hline $\mathrm{m}$ & 4249524 & 10596204 & 3816.300 & 1272779. & 1525.300 & 3835.000 \\
\hline im Sq. Dev. & $2.19 \mathrm{E}+10$ & $1.67 \mathrm{E}+13$ & 2315.860 & $4.26 \mathrm{E}+10$ & 8376.899 & 150242.5 \\
\hline bservations & 26 & 26 & 26 & 26 & 26 & 26 \\
\hline
\end{tabular}

Model is significant at 0.05 per cent which implies the model is adequate and can be used for decision making. In the test of significant of parameters in the model using t-test, the p-values of parameters are less than 0.05 per cent except that of SOL which is greater than 0.05 per cent. The p-values of t-test imply all parameters in the model are significant except SME. The coefficient of determination (R-Square) of the model is 62 per cent which implies the independent variables contributed up to 62 per cent to the fluctuation of the dependent variable.

Table 4.2c: Regression Result for the influence of Trade Openness on Capacity Building in the automobile industry in Nigeria.

Dependent Variable: CAPU

Method: Least Squares

Date: 03/21/16 Time: 12:54

Sample: 19902015

Included observations: 26 
Globalization And The Automobile Sector of Nigeria (1990-2015)

\begin{tabular}{lcccl}
\hline \hline Variable & Coefficient & Std. Error & t-Statistic & Prob. \\
\hline \hline C & 48.53849 & 1.113010 & 43.61011 & 0.0000 \\
TO & -2.331846 & 0.437076 & -5.335102 & 0.0000 \\
INDP & 0.026597 & 0.006766 & 3.930751 & 0.0007 \\
TT & 0.003229 & 0.001011 & 3.194327 & 0.0042 \\
\hline \hline R-squared & 0.805446 & Mean dependent var & 51.64615 \\
Adjusted R-squared & 0.778916 & S.D. dependent var & 0.663464 \\
S.E. of regression & 0.311958 & Akaike info criterion & 0.648740 \\
Sum squared resid & 2.140987 & Schwarz criterion & 0.842293 \\
Log likelihood & -4.433617 & Hannan-Quinn criter. & 0.704476 \\
F-statistic & 30.35980 & Durbin-Watson stat & 1.469227 \\
Prob(F-statistic) & 0.000000 & & & \\
\hline \hline & & & & \\
Mean & CAPU & INDP & TO & TT \\
Median & 51.64615 & 146.7808 & 0.545709 & 147.5000 \\
Maximum & 51.35000 & 145.8000 & 0.579541 & 131.5000 \\
Minimum & 52.80000 & 178.1000 & 0.856301 & 308.0000 \\
Std. Dev. & 0.60000 & 133.1000 & 0.215544 & 23.00000 \\
Skewness & 0.261158 & 1.872231 & -0.282668 & 0.730803 \\
Kurtosis & 1.689367 & 6.592682 & 2.036746 & 2.515653 \\
Jarque-Bera & 2.156455 & 29.17239 & 1.351419 & 2.568457 \\
Probability & 0.340198 & 0.000000 & 0.508795 & 0.276864 \\
Sum & 1342.800 & 3816.300 & 14.18842 & 3835.000 \\
Sum Sq. Dev. & 11.00462 & 2315.860 & 0.748659 & 150242.5 \\
Observations & 26 & & & \\
& & 26 & 26 & 26 \\
\hline
\end{tabular}

Model is significant at 0.05 per cent which implies the model is adequate and can be used for decision making. In the test of significant of parameters in the model using t-test, the p-values of parameters are all less than 0.05 per cent . The p-values of t-test imply all parameters in the model are significant. The coefficient of determination (R-Square) of the model is 80 per cent which implies the independent variables contributed up to 80 per cent to the fluctuation of the dependent variable.

\section{Discussion of Findings}

The research is on the influence of globalization on Nigerian automobile subsector using secondary data from reliable sources from the year 1990 to 2015. The research covers period of 26years with three specific objectives design based on the problem identified. Ordinary Least Square Regression was used. The following findings were discovered:

\subsection{Examine the extent of relationship between Foreign Direct Investments (FDI) and Manufacturing output of automobile industry in Nigeria;}

Table 4.2a represents the regression result of theextent of relationship between Foreign Direct Investments (FDI) and manufacturing output of automobile industry. An examination of the result presented above reveals the following; The Regression Equation shows that $\mathrm{MOT}=131.9223+1.21 \mathrm{E} .06 \mathrm{FDI}-1.93 \mathrm{E}-06 \mathrm{IMP}+0.034950 \mathrm{EXP}+1.27 \mathrm{E}-05 \mathrm{BOP}$.

Manufacturing Output is regressed on FDI, IMP, EXP and BOP.The model is significant at 0.05 per cent.The estimated coefficient of the constant term is 131.9223 and is statistically significant at 0.0 per cent. The coefficient for FDI carries a positive sign and to statistically significant at 0.04 per cent. This implies that FDI contributed to the level of manufacturing output in Nigeria automobile industries.

The coefficient of IMP carries a negative sign and is statistically significant at 0.01 per cent. This implies that IMP contributed to the level of manufacturing outputin Nigeria automobile industries.

The coefficient of EXP carries is a positive sign and is statistically not significant at 0.90 per cent. This signifies thatEXP did not contribute to the level of manufacturing output in the automobile industry in Nigeria.

The coefficient of BOP carries is a positive sign and is statistically significant at 0.01 per cent. This signifies that BOP contribute to the level of manufacturing output in the automobile industry in Nigeria. 
Globalization And The Automobile Sector of Nigeria (1990-2015)

The coefficient of R-Square $\left(\mathrm{R}^{2}\right)$ is 79 per cent indicating a high casual relationship between the dependent and independent variables.Adj $\mathrm{R}^{2}$ is 74 per cent showing that all the variables are corrected.

The value of Durbin Watson statistics (1.746475) is greater than $R^{2}(0.746475)$. This means that there is no case for auto correlation in the model and the result is respectable.

\subsection{Value added by Information and Communication Technology (ICT) penetration on Employment in the Automobile Industry in Nigeria ;}

Table $4.2 \mathrm{~b}$ represents the regression result of the value added by Information and Communication Technology (ICT) penetration on employment in the automobile industry in Nigeria. An examination of the result presented above reveals the following;

The Regression Equation shows that

$\mathrm{EMP}=208729.2+0.002248 \mathrm{FDI}-837.2237 \mathrm{INDP}-0.026411 \mathrm{MANT}+1189.659 \mathrm{SOL}+55.50812 \mathrm{TT}$.

Employment is regressed on FDI, INDP, MANT, SOL AND TT.The model is significant at 0.05 per cent.The estimated coefficient of the constant term is 208729.2 and is statistically significant at 0.03 per cent. The coefficient for FDI carries a positive sign and to statistically significant at 0.03 per cent. This implies that FDI contributed to the level of employmentin Nigeria automobile industries.

The coefficient of INDP carries a negative sign and is statistically significant at 0.00 per cent. This implies thatINDP contributed to the level of employmentin Nigeria automobile industries.

The coefficient of MANT carries is a negative sign and is statistically not significant at 0.90 per cent. This signifies thatMANT did not contribute to the level of employment in the automobile industry in Nigeria.

The coefficient of SOL carries is a positive sign and is statistically significant at 0.03 per cent. This signifies that Employment contributed to the level of SOL in Nigeria.

The coefficient of TT carries is a positive sign and is statistically significant at 0.05 per cent. This signifies that TT contributed to the level of employment in automobile industry in Nigeria.

The coefficient of R-Square $\left(\mathrm{R}^{2}\right)$ is 62 per cent indicating a high casual relationship between the dependent and independent variables.

$\operatorname{Adj} R^{2}$ is 52 per cent showing that all the variables are correlated.

The value of Durbin Watson statistics (2.768067) is greater than $R^{2}(0.621092)$. This means that there is no case for auto correlation in the model and the result is respectable.

\subsection{Influence of trade openness on capacity utilisation in the automobile industry in Nigeria}

Table $4.2 \mathrm{c}$ represents the regression result of theinfluence of trade openness on capacity utilisation in the automobile industry in Nigeria. An examination of the result presented above reveals the following;

The Regression Equation shows that

$\mathrm{CU}=48.53849-2.331846 \mathrm{TO}+0.026597 \mathrm{INDP}+0.003229 \mathrm{TT}$

Capacity Utilization is regressed on TT, TO, INDP.The model is significant at 0.05 per cent.The estimated coefficient of the constant term is 48.53849 and is statistically significant at 0.0 per cent. The coefficient for TO carries a negative sign and to statistically significant at 0.00 per cent. This implies that TO contributed to the level of capacity utilizationin Nigeria automobile industries.

The coefficient of TT carries a positive sign and is statistically significant at 0.00 per cent. This implies that TT contributed to the level of CAPUin Nigeria automobile industries.

The coefficient of INDP carries is a positive sign and is statistically significant at 0.00 per cent. This signifies thatCU contributed to the level of INDP in the automobile industry in Nigeria.

The coefficient of R-Square $\left(\mathrm{R}^{2}\right)$ is 80 per cent indicating a high casual relationship between the dependent and independent variables.

Adj $\mathrm{R}^{2}$ is 77 per cent showing that all the variables are correlated.

The value of Durbin Watson statistics (1.469227) is greater than $R^{2}(0.805446)$. This means that there is no case for auto correlation in the model and the result is respectable.

\section{Summary of Findings, Conclusion and Recommendations}

This chapter focuses on the summary of findings, conclusion and recommendations of the study as follows:

\subsection{Summary of Findings}

The broadobjective of the study is to examine theinfluence of globalisation on Nigerian automobile subsector. Specifically, the study seeks to examine the extent of relationship between Foreign Direct Investments (FDI) and manufacturing output of automobile industry, ascertain the value added by Information and 
Globalization And The Automobile Sector of Nigeria (1990-2015)

Communication Technology (ICT) penetration on employment in the automobile industry, and determine the influence of trade openness on capacity utilization in the automobile industry. The study utilized the Ordinary Least Square method of analysis using secondary data of required variables from the year 1990 to 2015. The regression resultofthe extent of relationship between Foreign Direct Investments (FDI) and Manufacturing output of automobile industry in Nigeria (4.2a) shows that Manufacturing Output increased as Foreign Direct Investment and Import increased while Export decreased. This finding is in agreement with the conclusions of Goldar et al (2010),Otepola (2002) and Ali et al (2012). The regression result of thevalue added by Information and Communication Technology (ICT) penetration on Employment in the Automobile Industry in Nigeria (4.2b) shows thatEmployment increased as Foreign Direct Investment, Industrial Production, Standard of Living and Technology Transfer while Manpower Training decreased. The result is in line with the conclusion of Banga (2004), Perre (2010), Nikolaj (2011), Wang (2008) and Mujamoto (2005).

The regression result of the influenceof trade openness on capacity utilization in the automobile industry in Nigeria (4.2c) shows that Capacity Utilization increased as Technology Transfer and Industrial Production increased while Trade Openness decreased. The result is in line with Satish (1999), Rash, (2004),Almas (2010), Akinlo (2004) and Sulaiman (2012).

\subsection{Conclusion}

For a country to maximally enjoy the benefits and minimize the risks associated with globalization, it has to develop and strength its capacity to timely identify both internal and external shocks, and to initiate, design and implement appropriate policies to forestall their destabilizing effects. It is on the basis of the foregoing that Nigeria can be put on the right track in the race towards sustainable development.

\subsection{Recommendations}

The following recommendations were made;

1. Nigeria should take a second look at her membership of the WTO and then selectively engage in those trades that will not jeopardize her national interest, most especially the imperative need to protect the manufacturing subsector.

2. Adequate preparations should be made in terms of relevant supply state measures and institutional arrangements to elicit the desired export supply responses before deep liberalization schemes are implemented.

3. Another approach to addressing the phenomena of globalization as it affects Nigeria in $21^{\text {st }}$ century is for African countries to encourage regionalism. The acceleration of the process of integration will boast the resource base of African countries thereby increasing the rate of growth and development.

\subsection{Contribution to the Knowledge}

The study was able to produce empirical evidence that Export does not have a significant effect on Manufacturing Output as it decreased while manufacturing output increased in the manufacturing industry, that Foreign Direct Investment, Industrial Production, Standard of Living and Technology Transfer is leading to an increase in employment level in the automobile industry and Capacity Utilization and Industrial Production is leading to an increase in Capacity Building in the automobile industry of Nigeria. This is suitable for potential entrepreneurs, business stakeholders and the Government of Nigeria in determining what initiative should be adopted to improve the impact of globalization on the manufacturing industry in the country and generate more revenues to the government through taxes and relief them of the endemic impact, unemployment poses to the economy.

Therefore, there is need for further research in the area of effect of globalization on organizational culture and trade unionism in Nigerian automobile sector.

\subsection{Suggestion for Further Studies}

Having critically examined the relationship between globalization and the automobile subsector of Nigeria, there is need for subsequent studies to incorporate other manufacturing subsector like the textile industry, agricultural industry, construction industry, mining industry and other related industries in the sameresearch. Again, studies in the future could also introduce and test more variables from the social and economic aspects of the society.

\section{References}


[1] Abdoulaye, S. (2011) International Technology to diffusion and economic growth: explaining the spillover benefits to developing countries structural change and Economic Dynamics 1-28.

[2] Abubakar, D (2001) Globalisation, Social Sciences and Nigeria in the $21^{\text {st }}$ century. The Nigeria social scientist, $4,1$.

[3] Adams, R (2004). Economic Growth, Inequality and Poverty Estimating the growth Elasticity of poverty World Development, 32,1989 $-2014$.

[4] Adelegan, J. (2000). "Foreign Direct Investment and economic growth in Nigeria: a seemingly unrelated model". African Review of Money, Finance and Banking, Supplementary issue of savings and Development 2000, Mileanpp.5-25.

[5] Adenikinju, A (2006). Productivity, Market Structure and Trade Liberalization in Nigeria Economic Development Department, Nigerian Institute of and economic Research (AERC). Research consortium: Nairobi, 2002 Nov.

[6] Adeolu, B. (2007). Foreign Direct Investment and Economic Growth: Evidence from Nigeria Department of Agricultural Economics, Obafemi Awolowo University, Ile-Ife, Nigeria AERC Research Paper 165, African Economic Research Consortuim, Nairobi.

[7] Aina, T (1996) Globalisation and Social Policy in Africa CODESRIA Bulletin 4.

[8] Akinlo, A. (2004). Foreign Direct Investment and growth in Nigeria: An empirical investigation, journal of policy modeling, 26, pp 627.

[9] Akinmulegun, S (2011), Globalisation, FDI and economic Growth in Nigeria 1986 - 2009, An Unpublished Ph.D thesis.

[10] Akinola, A (2004). Foreign Direct Investment and growth in Nigeria: An empirical investigation. Journal of policy modeling, 26, pp.62739.

[11] Alham, H. \&Subal, C. K. (2010). Technical Changes and total factor productivity growth: The case of Chinese province, 12A Discussion Paper No. 4784.

[12] Ali, H., Ahsan, A., Daniel, S., Wajiha, A., and Zahoor, S., (2012). Technology Spillover impacts on total factor productivity of the manufacturing sector in Pakistan. African Journal of Business Management, 6(9), 3490-3503.

[13] Alimi, Olorunfemi Y. and Atanda, A. (2011) Globalisation, Business cycle and Economic Growth African Journal of Scientific Research, Volume 7, No.1.

[14] Aluko, M (2004) Globalisation and the Manufacturing sector in journal of the Social Science Vol. 2 N0. 9

[15] Aminu, U (2013) Globalisation and its impact on the performance of the Nigeria Economy "in interdisciplinary Journal of research in Business Vol. 2 No. 8

[16] Anyanwu, J (2004). An Economic Investigations of the Determinants of Foreign Direct Investment in Nigeria. Proceeding of the 1988 NES Annual Conference, 219 - 241, Lagos.

[17] Asiedu, E (2001). On the Determinants of FDI to Developing Countries. Is Africa Different? World Development, 30(1), 107-119.

[18] Asiedu, E (2005). Foreign Direct Investment in Africa: The Role of Natural Resources, Market, Government Policy, Institutions and Instability. United Nations University, World Institute for Development Research. Research paper No. 2005/24, 1-15.

[19] Ayayi, I (2010) Nigeria, The trapped economy, Ibadan, Heinemann Educational Books Nigeria Limited.

[20] Benavente, J. (2004). In Defence of Globalisation, Oxford University Press,London.

[21] Central Bank of Nigeria statistical bulletin (various issues)

[22] Chukwudi, V (2013) An Empirical Analysis of the impact of globalisation on performance of Nigeria commercial Bank in Post consolation period in European Journal of Business and management, Vol. 5 N0 5.

[23] Clark, (1999).Globalisation and international relation theory, Oxford, Oxford University Press.

[24] Clark, W. C. (2000). Environmental Globalisation in Joseph S. Nye and John D. Donahoe (ed), Governance in a Globalisating World. Washington, D.C, Brookings Institute Press, pp 86-108.

[25] Clete, L. (1996). Productivity Growth in Nigerian Manufacturing and its correlation with Trade Policy Regime/ Indices, Research for Development, Vol. 11, No. 1.

[26] Dembele, D. (1998). "Africa in the Twenty-First Century" Codesria Bulletin 1.

[27] Dunning, J. (1988). Explaining International Production. London: Union Hyman.

[28] Dunning, J. (2002). The eclectic paradigin as an envelope for economic and business theories of MNE activity, International Business Review, Vol. 9. Pp. 163 - 190.

[29] Edward, S. (1993). Openness, Trade liberalization, and growth in developing countries.Journal of Economic literature 31, 1386-93.

[30] Edward, S. (1998). Openness, productivity and growth: What do we really know? Economic Journal 108, 383-98.

[31] Egwaiklude, F. (1997). "Import substitution industrialization in Nigeria, the Nigerian Journal of Economic and Social Studies, Vol. 39. No. 30

[32] Frankel, J. and Romer, D. (1999), "Dose Trade cause Growth?,” American economic Review, 89. No. 3 June, pp 379 - 99.

[33] Goldar, B. \& Kuman, A., (2003). Import Liberalization and productivity growth in India in the 1990s. the Developing Economics, 41(4), 436-460.

[34] Goldar, B. and Anita, K. (2003). Import liberalization and Productivity growth in India in the 1990s. The developing economics, 41 (4).

[35] Herzer, D. (2011). The long run relationship between outward foreign direct investment and total factor productivity.Evidence from developing countries, journal of Development Studies, 47.

[36] Hill, C. (2004). Global Business Today, Mc Growth Hill/Irwin, $3^{\text {rd }}$ ed. New York.

[37] Hopkins, A. (2004). "Globalisation in World History", Norton asked pp. $4-8$.

[38] Hwang, I. and Wang, E. (2004). Does openness to trade affect total factor productivity growth: Evidence from 45 Japanese's manufacturing industries, Journal of Economic Research, 9(3).

[39] Ihenvebere, J. (1999). Africa and the New Globalisation: Challenges and Options for the Future in Howard F. Didsbury Jr (ed). Future Vision: Ideas, insight and strategies.

[40] Jerome, A and Ogunakola (2004). Foreign Direct Investment (FDI) in Nigeria: Magnitude Direction and Prospects. Paper presented to the African Economic Research Consortium Special Seminar Series Nairobi, Poverty Alleviation CRERS.

[41] Kabiru, G. (2013). Globalisation and Trade Unions Challenges, Nigeria Manufacturing sector experience in European Scientific Journal, Vol. 2 N0 5.

[42] Kwanashie, M. (1999).Concepts and dimensions of globalisation in Nigeria Economic society Globalisation and Nigeria Economic Development Ibadan, NES.

[43] Mahadevan, R. (2002). Trade liberalization and productivity growth on Australian manufacturing industries.Atlantic Economic Journal.30(2)

[44] Manufacturing association of Nigeria (2004). 
[45] Mimiko, N. and Afolabi, O. (2008). Globalisation and Culture Revival in Africa what has Thing Fall Apart got to do with it?" conference on "Chinua Achebe and the Re-investing of Africa". Obafemi Awolowo University, Ile-Ife, Nig, June 16-19.

[46] Mita, B. (2004). Labour productivity, Import Competition and market structure in Australian manufacturing. Econometric Society, Vol 4. No. 48.

[47] Mohammed, E. (2005). Total factor productivity within the Tunisian manufacturing sectors and international convergence with OECD countries, Economic Research from, Beinit, 14-16.

[48] Nadiri, M. (2009). U. S. direct investment and the production structure of the manufacturing sector in France, Germany, Japan and the U.K, NBER working Paper.

[49] National Bureau of Statistics

[50] Nikolaj, M. (2011). Do Foreign Experts increase the productivity of domestic firms? 12A working Paper.Discussion paper No. 6001 (Oktoba).

[51] Nwezeaku, N. (2005). The impact of Globalisation on the Industrial growth of the Management Sciences, Vol. 7.N0 1.

[52] Obadan, M. (2004).Globalisation and Economic Management in African Proceeding of 2003 Annual conference of the Nigeria Economic.

[53] Obidike, P. (2013). An evaluation of the contribution of globalisation and capital account globalisation on economic development in international Research journal of Arts and Social Sciences vol. N0 8.

[54] Oguchi, N. (2008). Productivity of foreign and domestic firms in the Malaysian manufacturing industry Asian Economic Journal, 16(3), $215-228$.

[55] Ohiorlenuan, J. (2000). "The Past and Future of Development" A paper presented at the $41^{\text {st }}$ Annual Conference of the Nigerian economic Society.

[56] Olomola, A. (2003). Regional Integration in the context of Socio-Economic Transformations on African: Issues and Approaches in Ajakaiye and Olomola (eds); Research issues in the Management of Socio-Economic Transformation in Nigeria.

[57] Otepola, A. (2002). Foreign Direct Investment as a factor of economic growth in Nigeria Africa Institute for Economic Development and Planning (IDEP), Dakar Senegal.

[58] Parviz, A. (2011). Economic growth determinants and foreign direct investment causality in Canada International Journal of Business and Social Sciences, 2(11), 1-9.

[59] Pessoa, A (2005) Foreign Direct Investment and Total factor productivity in OECD countries: Evidence from aggregate data. Working Papers Faculdade de Economia University of Parto.Working Paper No. 188.

[60] Peter, Z. (2006). FDI and OECD Industry Productivity: Technology, capital and country size. International Business School, Brandies University.

[61] Saches, J and Warner, A. (1995). Economic reform and the process of global integration, Brookings Papers on Economic Activity 1.

[62] Satish, C. (1999). Trade Liberalization and productivity growth: Time - series evidence from Australian manufacturing. The economic Record, 75 (227, 28-36).

[63] Satish, C. (2003). Trade liberalization and productivity growth: Time - series evidence from Australian manufacturing. The Economic Record, 75 (228).

[64] Savides, A. and Zachariadia, M (2005).International technology diffusion and the growth of TFP in the manufacturing sector of developing economics.Review of Development Economics, 9(4). $482-501$.

[65] Schiff, M and Wang, Y. (2008). North-South and South - South trade related technology diffusion: How important are they in improving Studies, 44(1), $49-59$.

[66] Sulaman, N. (2012). The impact of globalization on Total factor Productivity of the manufacturing sector in Malaysia, ProsidingPerkem Vol 11, jilid, 1, 4.9-422

\section{Appendix 1}

Foreign Direct Investments and Manufacturing Output in Nigeria (1990 -2015)

\begin{tabular}{|l|l|l|l|l|l|}
\hline YEAR & MOT & BOP & FDI & IMP & EXP \\
\hline 1990 & 102.4000 & 18498.2 & 6916.1 & 45717.9 & 405.5 \\
\hline 1991 & 117.4000 & 5959.6 & 14463.1 & 89488,2 & 472 \\
\hline 1992 & 132.8000 & 65271.8 & 29675.2 & 143151.2 & 244.4 \\
\hline 1993 & 94.80000 & 13615.9 & 75940.6 & 165629.4 & 227.8 \\
\hline 1994 & 83.40000 & 42623.3 & 111299 & 162788.8 & 244.4 \\
\hline 1995 & 100.0000 & 195316.3 & 110452.7 & 755127.7 & 285.7 \\
\hline 1996 & 96.1000 & 53152 & 110456.7 & 562626.6 & 927.57 \\
\hline 1997 & 128.4000 & 38076.3 & 80750.4 & 845716.6 & 128.62 \\
\hline 1998 & 135.2000 & 220675.1 & 92792.5 & 837418.7 & 121.25 \\
\hline 1999 & 154.3000 & 326634.3 & 115952.2 & 863515.7 & 117.79 \\
\hline 2000 & 162.9000 & 314139,2 & 132481 & 985022.4 & 116.95 \\
\hline 2001 & 178.1000 & 24738.7 & 252248 & 1358180.3 & 192.09 \\
\hline 2002 & 169.200 & 563483.9 & 374937.7 & 1512695.3 & 183.98 \\
\hline 2003 & 145.2000 & 162298.4 & 417175.4 & 2080235.3 & 164.94 \\
\hline 2004 & 144.200 & 1124157.2 & 455316 & 1987045.3 & 299.31 \\
\hline 2005 & 136.2000 & 1362253.9 & 415809.7 & 2800856.3 & 448.95 \\
\hline 2006 & 138.7000 & 1772650.9 & 429433.7 & 3108519.3 & 714.06 \\
\hline 2007 & 138.5000 & 1666525.4 & 433519.8 & 3911952.6 & 718.11 \\
\hline 2008 & 133.1000 & 992282.3 & 431476.7 & 5189802.6 & 795.04 \\
\hline 2009 & 133.1000 & 1862597.8 & 4322498.2 & 5102534.4 & 968.02 \\
\hline 2010 & 133.7000 & 305561.31 & 4376.98 & 7614440.5 & 881.53 \\
\hline 2011 & 138.2000 & 831406.39 & 449501.6 & 10237453 & 924.77 \\
\hline
\end{tabular}


Globalization And The Automobile Sector of Nigeria (1990-2015)

\begin{tabular}{|l|l|l|l|l|l|}
\hline 2012 & 142.2000 & 1949196.9 & 415609.7 & 8342000.2 & 903.15 \\
\hline 2013 & 146.3000 & 1209069.8 & 421436.7 & 8012000.4 & 913.96 \\
\hline 2014 & 148.0000 & 2046779 & 459501.5 & 21250120 & 933.87 \\
\hline 2015 & 145.5 & 1735015.2 & 432182.6 & 12534706.9 & 917 \\
\hline
\end{tabular}

Source: Central Bank of Nigeria Statistical Bulletin (various issues) National Bureau of Statistics

\section{KEYS}

MOT = Manufacturing Output

FDI $=$ Foreign Direct Investment

$\mathrm{BOP}=$ Balance of Payment

IMP $=$ Import

$\mathrm{EXP}=$ Export

\section{Appendix 2}

Information and Communication Technology Penetration and Employment in Nigeria (1990-2015)

\begin{tabular}{|l|l|l|l|l|l|l|}
\hline YEAR & EMP & FDI & TT & MANT & INDP & SOL \\
\hline 1990 & 99934 & 6916.1 & 23 & 653.5 & 162.9 & 31.6 \\
\hline 1991 & 123137 & 14463.1 & 116 & 1084.1 & 178.1 & 36.4 \\
\hline 1992 & 97349 & 29675.2 & 277 & 1941.8 & 169.5 & 31.3 \\
\hline 1993 & 183540 & 75940.6 & 240 & 2294.6 & 145.5 & 31.6 \\
\hline 1994 & 100400 & 111299 & 131 & 1554.2 & 144.2 & 36.4 \\
\hline 1995 & 114672 & 110452.7 & 276 & 2060.4 & 136.2 & 31.3 \\
\hline 1996 & 152593 & 110456.7 & 218 & 7999.1 & 138.7 & 31.6 \\
\hline 1997 & 184103 & 80750.4 & 308 & 10283.8 & 138.5 & 36.4 \\
\hline 1998 & 149693 & 92792.5 & 294 & 12728.7 & 133.1 & 54 \\
\hline 1999 & 190328 & 115952.2 & 181 & 15351.8 & 137.7 & 54 \\
\hline 2000 & 170287 & 132481 & 116 & 15944.0 & 142.2 & 65.4 \\
\hline 2001 & 180311 & 252248 & 141 & 26721.3 & 146.3 & 65.3 \\
\hline 2002 & 180309 & 374937.7 & 132 & 31563.8 & 148 & 66.3 \\
\hline 2003 & 180308 & 417175.4 & 93 & 67568.1 & 145.7 & 66.5 \\
\hline 2004 & 176960 & 455316 & 95 & 59744.6 & 145.8 & 67.3 \\
\hline 2005 & 179196.3 & 415809.7 & 98 & 109455.2 & 145.9 & 71.2 \\
\hline 2006 & 178824.7 & 429433.7 & 70 & 79436.1 & 145.8 & 76.4 \\
\hline 2007 & 178330 & 433519.8 & 67 & 93767.9 & 145.8 & 73.2 \\
\hline 2008 & 178783.7 & 431476.7 & 87 & 94219.7 & 145.8 & 77.6 \\
\hline 2009 & 178646.1 & 4322498.2 & 79 & 89141.2 & 145.8 & 67.6 \\
\hline 2010 & 178586.6 & 4376.98 & 90 & 92376.2 & 145.8 & 73.4 \\
\hline 2011 & 178672.1 & 449501.6 & 83 & 90758.7 & 145.8 & 76.5 \\
\hline 2012 & 178629.3 & 415609.7 & 146 & 91660.3 & 145.8 & 78.1 \\
\hline 2013 & 178650.7 & 421436.7 & 149 & 91598.4 & 145.8 & 76 \\
\hline 2014 & 178640 & 459501.5 & 170 & 91339.1 & 145.8 & 73.9 \\
\hline 2015 & 178640 & 432182.6 & 155 & 91532.6 & 145.8 & 76 \\
\hline
\end{tabular}

Source: Central Bank of Nigeria Statistical Bulletin (various issues) National Bureau Statistics

\section{KEYS}

EMP = Employment

FDI $=$ Foreign Direct Investment

$\mathrm{TT}=$ Technology Transfer

MANT $=$ Manpower Training

INDP $=$ Industrial Production

$\mathrm{SOL}=$ Standard of Living

\section{Appendix 3}

Trade Openness and Capacity Utilization in the automobile industry in Nigeria (1990-2015)

\begin{tabular}{|l|l|}
\hline YEAR & T'T \\
\hline 1990 & 23 \\
\hline 1991 & 116 \\
\hline 1992 & 27 \\
\hline 1993 & 240 \\
\hline 1994 & 131 \\
\hline 1995 & 276 \\
\hline
\end{tabular}

\begin{tabular}{|l|l|l|l|}
\hline TT & CAPU & TO & INDP \\
\hline 23 & 52 & 0.469096 & 162.9 \\
\hline 116 & 52.8 & 0.501114 & 178.1 \\
\hline 277 & 52.7 & 0.386737 & 169.5 \\
\hline 131 & 52.6 & 0.308928 & 145.5 \\
\hline 276 & 52.5 & 0.272822 & 144.2 \\
\hline
\end{tabular}

DOI: 10.9790/487X-180902116139 
Globalization And The Automobile Sector of Nigeria (1990-2015)

\begin{tabular}{|l|l|l|l|l|}
\hline 1996 & 218 & 52.3 & 0.215544 & 138.7 \\
\hline 1997 & 308 & 52.2 & 0.458287 & 138.5 \\
\hline 1998 & 294 & 52.2 & 0.37844 & 133.1 \\
\hline 1999 & 181 & 52 & 0.409744 & 137.7 \\
\hline 2000 & 116 & 52 & 0.581588 & 142.2 \\
\hline 2001 & 141 & 51.8 & 0.676055 & 146.3 \\
\hline 2002 & 132 & 51.1 & 0.654132 & 148 \\
\hline 2003 & 93 & 51.2 & 0.562095 & 145.7 \\
\hline 2004 & 95 & 51 & 0.409893 & 145.8 \\
\hline 2005 & 98 & 50.6 & 0.856301 & 145.9 \\
\hline 2006 & 70 & 50.8 & 0.692699 & 145.8 \\
\hline 2007 & 67 & 50.9 & 0.744968 & 0.642289 \\
\hline 2008 & 87 & 51 & 0.645874 & 145.8 \\
\hline 2009 & 79 & 51.3 & 0.688475 & 145.8 \\
\hline 2010 & 90 & 51.4 & 0.603159 & 145.8 \\
\hline 2011 & 83 & 51.1 & 0.743848 & 145.8 \\
\hline 2012 & 146 & 51.1 & 0.577495 & 145.8 \\
\hline 2013 & 149 & 51.3 & 0.743848 & 145.8 \\
\hline 2014 & 170 & 51.3 & 0.688397 & 145.8 \\
\hline 2015 & 155 & 51.2 & 145.8 \\
\hline
\end{tabular}

Source: Central Bank of Nigeria Statistical Bulletin (various issues) National Bureau Statistics

\section{KEYS}

TT $=$ Technology Transfer

CAPU $=$ Capacity Utilization

INDP = Industrial Product

$\mathrm{TO}=$ Trade Openness 